\title{
KUPU-KUPU TERSEMBUNYI PENERUS BANGSA DI TPA SUKAWINATAN
}

\author{
Lisnani $^{1}$, Maria Oktavia Nira Tania Beda ${ }^{2}$, Thessalonika Elma La Septi Manik ${ }^{3}$, Benediktha \\ Evi Fani Puji Lestari ${ }^{4}$, Titus DwiantoPrasetyo ${ }^{5}$, Wenny Angeliana ${ }^{6}$ \\ 1,2Program Studi PGSD, Fakultas Humaniora dan Ilmu Pendidikan, Universitas Katolik Musi Charitas \\ ${ }^{3}$ Program Studi PBI, Fakultas Humaniora dan Ilmu Pendidikan, Universitas Katolik Musi Charitas \\ ${ }^{4}$ Program Studi Akuntansi, Fakultas Bisnis dan Akuntansi, Universitas Katolik Musi Charitas \\ ${ }^{5}$ Program Studi Manajemen, Fakultas Bisnis dan Akuntansi, Universitas Katolik Musi Charitas \\ ${ }^{6}$ Program Studi Teknik Industri, Fakultas Bisnis dan Akuntansi, Universitas Katolik Musi Charitas \\ Email: lisnani@ukmc.ac.id
}

\begin{abstract}
Hidden butterfly of the successor to the nation is a form of devotion conducted by students from different study programs with lecturers. This activitywas carried out by five students from different study programs namely Primary School Teacher Education, English Education, Management, Accounting, and Industrial Engineering. The purpose of this activity is to equip children of TPA Sukawinatan with the following: 1) improving the ability to read, write and count (calistung); 2) improve English language skills; 3) applywise attitude in using money; 4) In stilling good character of management (arrangement) and time discipline in children; 5) Developing children's skills in utilizing used goods to be made as something that has added value. The method of implementation used in the form of preparation, planning and implementation stages. Methods of practice, experiments, lectures and games. The results of this activity are as follows: 1) increased ability to read, write and count; 2) increasing English language skills; 3 ) understanding the importance of using money wisely; 4) has a management character (discipline) of time; 5) have skills in utilizing used goods to become something that has added value.
\end{abstract}

Keywords: hidden butterflies, calistung, English, use of money, time discipline, processing used goods

\begin{abstract}
$\boldsymbol{A} \boldsymbol{b}$ strak. Kupu-kupu tersembunyi penerus bangsa adalah bentuk kegiatan pengabdian yang dilakukan oleh mahasiswa dari program studi berbeda bersama dosen. Kegia tan ini dila kukan oleh lima orang mahasiswa dari program studi yang berbeda-beda yaitu Pendidikan Guru Sekolah Da sar, Pendidikan Bahasa Inggris, Ma najemen, Akuntansi, dan Teknik Industri. Tujuan dari kegia tan in i a dalah membekali anak-anak TPA Sukawinatan dengan hal berikut: 1) meningkatkan k emampuan membaca, menulis da n berhitung (calistung); 2) meningkatkan kemampuan berbahasa Inggris; 3 ) menerapkan sikap bijaksana dalam menggunakanuang; 4) Menanamkan karakter manajemen (pengaturan) dan disiplin waktu yang baik pada anak-anak; 5) Menumbuhkembangkan keterampilan a nak-anak dalam memanfaatkan barang bekas untuk dijadikan sesuatu yang memiliki nilai ta mbah. Metode pelaksanaan yang digunakan dalam bentuk tahap persiapan, perencanaan dan pe laksanaan. Metode praktik, eksperimen, ceramah, dan permainan. Hasil da ri kegia tan ini a dalah sebagai berikut: 1) meningkatnyakemampuan membaca, menulis dan berhitung; 2) m eningkatnya kemampuan bahasa Inggris;3) memahami pentingnya penggunaan uang dengan bijak; 4) m emiliki ka rakter manajemen (disiplin) waktu; 5) memiliki keterampila ndalam memanfaatkan barang be ka s untuk dija dikan sesuatu yang memiliki nilai ta mbah.
\end{abstract}

Kata Kunci: Kupu-kupu tersembunyi, calistung, bahasa Inggris, penggunaan uang, di siplin waktu, pengolahan barang bekas

\section{PENDAHULUAN}

Pendidikan memegang peranan penting untuk mengakhiri kemiskinan dan mengurangi kesenjangan sosial, baik di Indonesia maupun di negara lain serta meningkatkan kesejahteraan hidup masyarakat. Keberadaan pendidikan di
Indonesia membuat masyarakat memiliki pola pikir yang maju dan daya saing yang tinggi di era globalisasi ini. Namun sepertinya hal tersebut tidak berlaku di Indonesia. Berdasarkan website www.pikiranrakyat.com/pendidikan/2017/03/17/s oal-minat-baca-indonesia-peringkat-60dari-61- 
negara-396477 dari hasil studi "Most Littered Nation in The World" yang dilakukan oleh Central Connecticut State University pada Maret 2016 silam, Indonesia menduduki peringkat ke60 dari 61 negara yang terdata, soal minat membaca masyarakatnya.

Kemudian data laporan PISA (Programme for International Student Assessment) di tahun 2015 dituliskan bahwa Indonesia menempati posisi ke-62 untuk kualitas sistem pendidikan dari 72 negara yang tercatat, dengan kata lain masyarakat Indonesia masih kurang berkontribusi dan berpartisipasi aktif dalam terlaksananya edukasi yang baik dan layak (dalam website https://data.oecd.org/indonesia.htm).

Tim pelaksana telah melakukan beberapa observasi terkait dengan kegiatan yang dilakukan oleh anak-anak pada jenjang usia TK hingga SMP kelas 1 yang bertempat tinggal di pelosokpelosok daerah. Sebagian anak-anak di daerah tersebut ada yang sudah bersekolah dan sebagiannya lagi belum bersekolah dikarenakan dari segi ekenomi mereka yang belum mencukupi. Salah satunya adalah mereka yang tinggal di wilayah TPA 1 Sukawinatan RT 068 RW 010 Kec. Sukarami Kel. Sukajaya, Palembang. Sebagian besar orang tua dari anakanak di TPA tersebut bermata pencaharian sebagai pemulung. Hal ini dikarenakan tuntutan dan kebutuhan hidup yang harus mereka penuhi, mereka diharuskan menukar kesempatan bersekolah dengan membantu orangtua mereka mengais rezeki ditumpukan barang bekas.

Namun, di sela kegiatan mereka membantu orangtua, mereka selalu menyempatkan waktu untuk ikut dalam kegiatan belajar-mengajar sederhana yang dilakukan oleh sekelompok sukarelawan pada setiap hari Rabu dan Sabtu. Semangat dan ketertarikan mereka terhadap pendidikan sangat tinggi. Namun tim pelaksana melihat bahwa kesempatan bagi mereka untuk mengembangkan minat dan kemampuan masih belum ada sehingga melalui kegiatan Program Kreativitas Mahasiswa bidang Pengabdian kepada Masyarakat ini, tim pelaksana hendak memfasilitasi semangat belajar mereka.

Berdasarkan hasil observasi awal terhadap pihak mitra yang dilakukan oleh tim pelaksana diperoleh permasalahan yang dihadapi oleh mitra yaitu kemampuan anak-anak di TPA Sukawinatan di bidang Calistung (termasuk matematika), Bahasa Inggris, pengelolaan keuangan, dan kreativitas masih terbatas dan hal ini terlihat dari antusiasme pihak mitra terhadap kehadiran tim pelaksana pengabdian selama proses pembelajaran berlangsung. Padahal di dalam matematika, terdapat materi operasi hitung dasar yang terdiri dari empat operasi hitung dasar yaitu: (1) Penjumlahan, yaitu operasi hitung untuk memperoleh dua bilangan bulat atau lebih; (2) Pengurangan, yaitu operasi hitung untuk memperoleh selisih dari dua bilangan atau lebih; (3) Perkalian, yaitu penjumlahan berulang dengan penjumlahan tetap; dan (4) Pembagian, yaitu pengurangan berulang dengan pengurangan tetap, selanjutnya bentuk operasi kali yang berulang adalah operasi pangkat (Lisnani, dkk., 2020: 21).

Berdasarkan permasalahan di atas, tim pelaksana berinisiatif untuk membantu pihak mitra untuk memberikan materi pelatihan dalam bentuk pembelajaran sesuai dengan bidang ilmu dari masing-masing anggota. Mulai dari bidang ilmu Pendidikan Guru Sekolah Dasar akan memberikan materi pembelajaran membaca, menulis, dan berhitung yang merupakan dasar bagi seseorang untuk bisa berkomunikasi dengan baik terhadap orang lain. Kemudian dari bidang ilmu Akuntansi akan memberikan edukasi tentang pentingnya menabung dan cara menggunakan uang secara bijak dan bertanggung jawab untuk membentuk anak menjadi pribadi yang tidak boros di kemudian hari.

Selanjutnya, bidang Teknik Industri jug a akan mengajarkan cara mengolah barang bekas untuk dijadikan sesuatu yang memiliki nilai fungsi dan nilai jual sehingga membentuk jiwa kewirausahaan anak secara perlahan dan mengajarkan kepada anak untuk bisa mencintai lingkungan. Tak hanya itu, dari bidang Manajemen pun juga akan memberikan anakanak edukasi tentang pentingnya disiplin waktu dan cara membiasakan diri untuk disiplin dengan latihan membuat jadwal harian. Kemudian yang terakhir dari bidang Pendidikan Bahasa Inggris akan memberikan materi pembelajaran tentang 
bahasa Inggris yang biasa digunakan dalam kehidupan sehari-hari supaya anak-anak tetap bisa mengikuti perkembangan zaman sekarang yang semakin modern dengan teknologi yang berbasis bahasa Inggris.

Adapun luaran yang dihasilkan dalam kegiatan ini adalah sebagai berikut: 1) anak-anak memiliki kemampuan membaca, menulis dan berhitung yang baik; 2) anak-anak memiliki sikap bijaksana dan bertanggung jawab dalam hal penggunaan uang; 3) anak-anak memiliki keterampilan dalam memanfaatkan barang bekas sehingga membantu dalam pelaksanaan pelestarian lingkungan; 4) anak-anak memiliki karakter manajemen (pengaturan) dan disiplin waktu yang baik; 5) anak-anak memiliki pengetahuan dan kemampuan ber-Bahasa Inggris sederhana dalam kehidupan sehari-hari. Maka dari itu, kegiatan yang tim pelaksana lakukan ini seluruhnya akan dikemas dalam suatu sistem pembelajaran sederhana yang menarik bagi anakanak yang tinggal di sekitar TPA 1 Sukawinatan dengan judul "Kupu-kupu Tersembunyi Penerus Bangsa" supaya mereka juga berkesempatan untuk merasakan indahnya pendidikan.

\section{METODE PELAKSANAAN}

Metode pelaksanaannya dibagi menjadi 3 tahap:

1. Tahap Perencanaan

Pada tahap ini tim pelaksana melakukan pengamatan (observasi) terhadap pihak mitra dan lingkungan sekitar. Pada tahap awal, tim pengabdian mengobservasi lokasi pelaksanaan program, serta mendata keperluan yang akan digunakan dalam proses pelaksanaan program. Lokasi yang dipilih adalah TPA 1 Sukawinatan RT 068 RW 010 Kec. Sukarami Kel. Sukajaya, Palembang. Keperluan utamanya adalah tempat belajar serta sistem pembelajaran yang lebik memadai. Maka dari itu, tim pelaksana merancang program penerapan sistem pendidikan sederhana yang hampir setara dengan pendidikan formal. Kemudian, tim pelaksana mengurus surat perijinan serta surat pernyataan kesediaan kerja sama dengan RT setempat. Kemudian tim pelaksana mengurus surat perijinan serta surat pernyataan kesediaan kerja sama dengan RT setempat.

2. Tahap Pelaksanaan

Pada tahap ini, tim pelaksana mulai melakukan persiapan dan pembelian barang yang diperlukan dalam pelaksanaan program kegiatan ini. Kemudian tim melakukan pendekatan dan sosialisasi dengan masyarakat sasaran terlebih dahulu guna menyiapkan tempat yang layak untuk mengaplikasikan program kami. Pelaksanaan kegiatan dilakukan dalam bentuk pelatihan oleh tim pelaksana sesuai dengan bidang keahlian dari masing-masing tim. Jumlah peserta yang terlibat dalam kegiatan yang tim pelaksana selenggarakan sebanyak 40 anak dengan rentang usia dari 3 tahun sampai 13 tahun. Jadwal pelaksanaan kegiatan dapat dilihat pada Tabel 1 berikut.

Tabel 1.Jadwal Pelaksanaan Kegiatan

\begin{tabular}{ccl}
\hline No. & Tanggal & \multicolumn{1}{c}{ Kegiatan } \\
\hline 1 & 14 Juni2019 & Materi membaca, menulis, dan berhitung \\
\hline 2 & 15 Juni2019 & Praktik membaca, menulis, dan berhitung \\
\hline 3 & 17 Juni2019 & Edukasi tentang penghematan uang dan fungsi menabung \\
\hline 4 & 18 Juni2019 & Nama pahlawan pada pecahan mata uang \\
\hline 5 & 21 Juni2019 & Praktik pengolahan kertas bekas menjadi kertas dekoratif \\
\hline 6 & 22 Juni2019 & Praktik pengolahan gelas plastik bekas menjadicelengan berkarakter. \\
\hline 7 & 24 Juni2019 & Edukasi tentang manajemen wa ktu \\
\hline 8 & 25 Juni2019 & Praktik membuat jadwalharian. \\
\hline 9 & 5 Juli 2019 & Membaca teks perkenalan dengan Bahasa Inggris \\
\hline 10 & 6 Juli 2019 & $\begin{array}{l}\text { Belajar kosa kata Bahasa Inggris (vocabulary) melalui permain an dan } \\
\text { bernyanyi bersama }\end{array}$ \\
\hline
\end{tabular}


3. Tahap Evaluasi

Selama kegiatan Program Kreativitas Mahasiswa ini dilaksanakan, tim pelaksana melakukan analisis dan evaluasi guna mencari apakah terdapat kendala atau tidak. Di samping itu, tim pelaksana memberikan kuesioner guna mengetahui bagaimana respon masyarakat sasaran terhadap keseluruhan kegiatan yang dilaksanakan oleh tim pelaksana. Dengan kata lain, tim pelaksana memastikan bahwa program dapat diterima baik oleh masyarakat sasaran. Kemudian, tim pelaksana akan menarik simpulan terkait proses pelaksanaan program dan membuat laporan sebagai bentuk tanggung jawab tim pelaksana terhadap program yang telah selesai dilaksanakan.

\section{HASIL DAN PEMBAHASAN}

Tim pelaksana telah menyelesaikan kegiatan Program Kreativitas Mahasiswa Pengabdian kepada Masyarakat dengan judul "Kupu-kupu Tersembunyi Penerus Bangsa" dari bulan April sampai dengan bulan Agustus di TPA 1 Sukawinatan. Program Kreativitas Mahasiswa ini merupakan program rutin yang diadakan oleh Lembaga Layanan Pendidikan Tinggi Wilayah II. Kegiatan Program Kreativitas Mahasiswa (PKM) bidang Pengabdian kepada Masyarakat yang dilaksanakan oleh tim pelaksana menjadi beberapa kegiatan antara lain sebagai berikut: 1) pengajaran dan pembelajaran terkait dengan membaca, menulis, berhitung (calistung); 2) edukasi penggunaan uang secara bijak dan bertanggung jawab; 3) keterampilan mengolah barang bekas; 4) edukasi disiplin waktu dengan menyusun jadwal harian; 5) penggunaan Bahasa Inggris dalam percakapan sehari-hari kepada anak-anak di TPA 1 Sukawinatan.

Jumlah peserta yang terlibat dalam kegiatan yang tim pelaksana selenggarakan sebanyak 40 anak dengan rentang usia dari 3 tahun sampai 13 tahun kegiatan PKM yang dilaksanakan oleh tim pelaksana dibagi menjadi 5 kegiatan inti, yaitu sebagai berikut:

1. Pembelajaran Membaca, Menulis, dan Berhitung (Calistung)

Pada saat tim pelaksana melakukan observasi lapangan ke tempat sasaran, terlihat bahwa kemampuan peserta (anak-anak) dalam hal membaca, menulis, dan berhitung belum cukup baik, bahkan ada yang belum mengenal huruf. Namun, setelah tim pelaksana mengadakan pembelajaran terkait materi membaca, menulis, dan berhitung, peserta yang sangat antusias mengikuti setiap materi yang diberikan memperoleh hasil pencapaian yang cukup signifikan. Mereka lebih mamahami cara membaca, menulis, dan berhitung dengan baik. Keseluruhan kegiatan pembelajaran calistung ini seperti pada Gambar 1 dan Gambar 2 berikut.

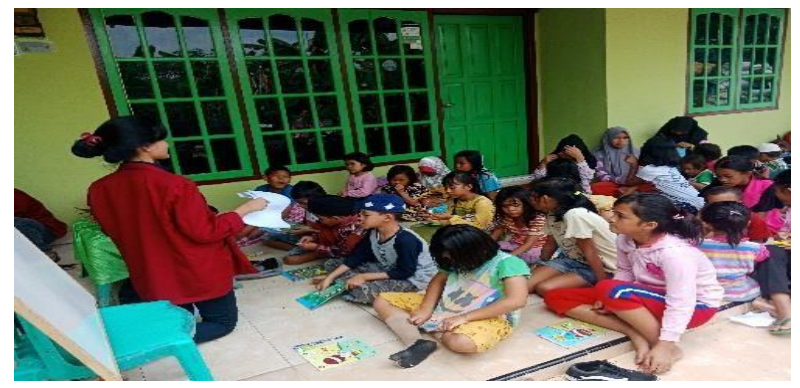

Gambar 1. Penyampaian Materi Pengenalan Bangun Datar dan Operasi Hitung Bilangan

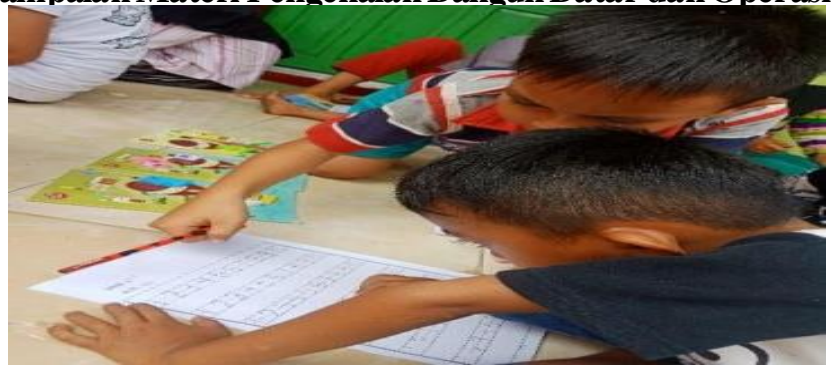

Gambar 2. Anak-anak Melakukan Latihan Menulis Pola Huruf dan Membaca 
Anak-anak pada rentang usia 3-6 tahun sudah mulai bisa mengikuti latihan membuat pola huruf alfabet yang tim pelaksana berikan. Sedangkan untuk anak-anak pada rentang usia 7-13 tahun sudah mulai memahami bangun datar dan perhitungan angka secara komunikatif dan distributif.

2. Edukasi Penggunaan Uang Secara Bijak dan Bertanggung Jawab

Sebelum tim pelaksana melakukan pengajaran kepada peserta (anakanak) di TPA 1 Sukawinatan, saat observasi lapangan tim pelaksana melihat bahwa anak-anak diberikan uang saku oleh orangtua mereka, dan tim pelaksana melihat bahwa beberapa dari mereka ada yang menyimpan sebagian uang saku tersebut, tetapi ada juga yang menghabiskannya pada hari itu juga. Namun, setelah tim pelaksana memberikan mereka edukasi terkait pentingnya menabung dan bagaimana cara menggunakan uang secara bijak dan bertanggung jawab, peserta yang sangat antusias mengikuti edukasi tersebut perlahan-lahan mulai menyisihkan uang saku mereka untuk membeli barang-barang keperluan mereka yang lainnya. Kegiatan edukasi penggunaan uang secara bijak dan bertanggung jawab seperti Gambar 3 berikut.

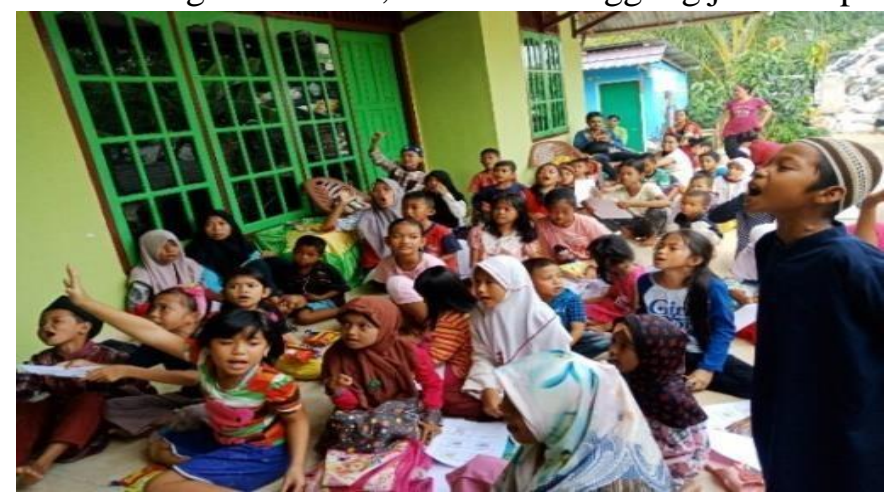

Gambar 3. Anak-anak Sangat Antusias Ketika Menjawab Pertanyaan yang Diberikan

3. Keterampilan Mengolah Barang Bekas Selama melakukan observasi lapangan, kegiatan belajar mengajar yang diadakan oleh komunitas MASIH belum terdapat pembelajaran terkait keterampilan mengolah barang bekas. Maka dari itu, saat tim pelaksana mengadakan pembelajaran keterampilan ini pada hari pelaksanaan kelima dan keenam, para peserta sangat antusias dan benar-benar menuangkan segal a kreasi mereka ke dalam praktik mengolah kertas bekas menjadi kertas dekoratif dan mengolah gelas plastic bekas menjadi celengan berkarakter. Hasil yang dibuat oleh para peserta dapat dilihat pada Gambar 4 dan Gambar 5 berikut.

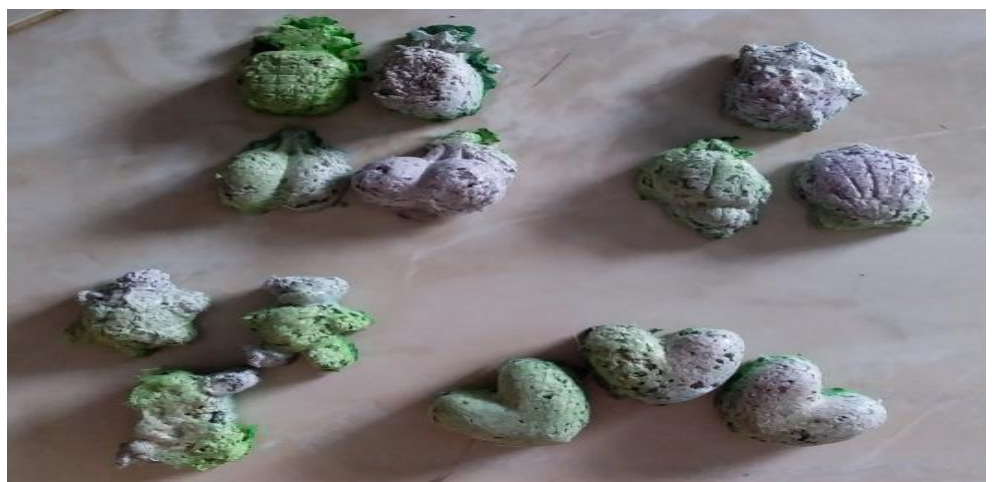

Gambar 4. Hasil Kertas Dekoratif yang Dibuat Peserta dari Kertas Bekas 


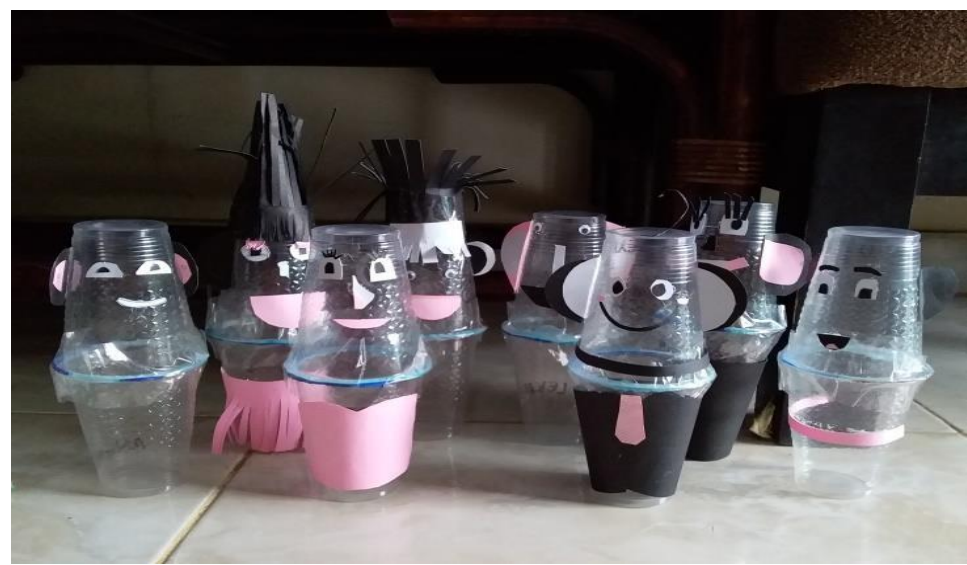

\section{Gambar 5. Hasil Celengan Karakter yang Dibuat Peserta dari Gelas Plastik Bekas}

setelah belajar juga mereka kembali bermain.

4. Edukasi Disiplin Waktu dengan Menyusun Jadwal Harian

Sebelum melakukan edukasi disiplin waktu, tim pelaksana dapat menyimpulkan dari hasil observasi lapangan yang dilakukan dengan komunitas MASIH bahwa peserta masih belum menerapkan disiplin waktu dalam kehidupan sehari-hari karena dapat dilihat bahwa beberapa anak-anak seusai pulang sekolah bermain sembari menunggu waktu belajar bersama komunitas MASIH tiba, dan
Tetapi setelah tim pelaksana memberikan edukasi terkait dengan disiplin waktu dengan menyusun jadwa harian, peserta dengan sangat antusias membuat jadwal harian pada selembar form jadwal yang telah tim pelaksana berikan dan mereka mencoba untuk mengikuti jadwal tersebut dengan baik sehingga dapat lebih menghargai waktu yang ada. Kegiatan yang dilakukan oleh tim pelaksana seperti Gambar 6 dan Gambar 7 berikut.

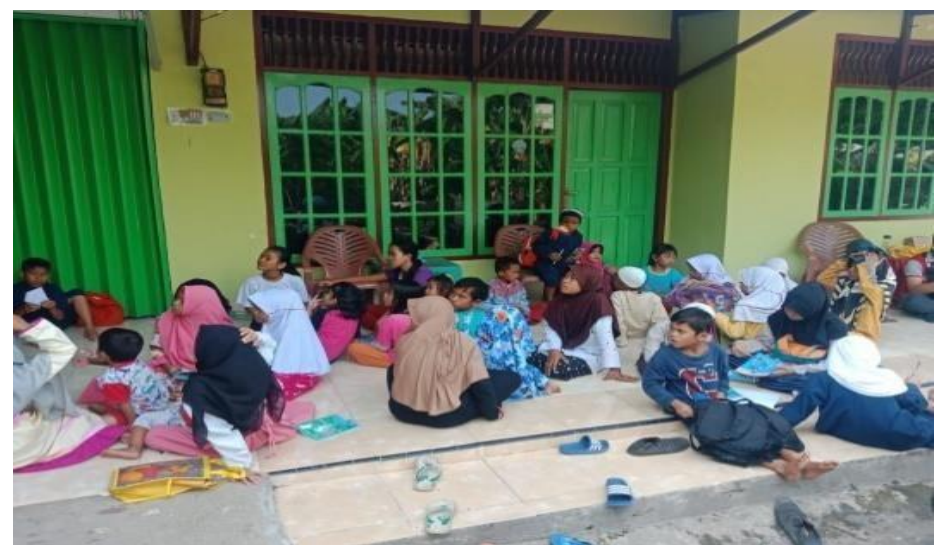

Gambar 6. Anak-anak Menonton Film Animasi Anak Tentang Disiplin Waktu

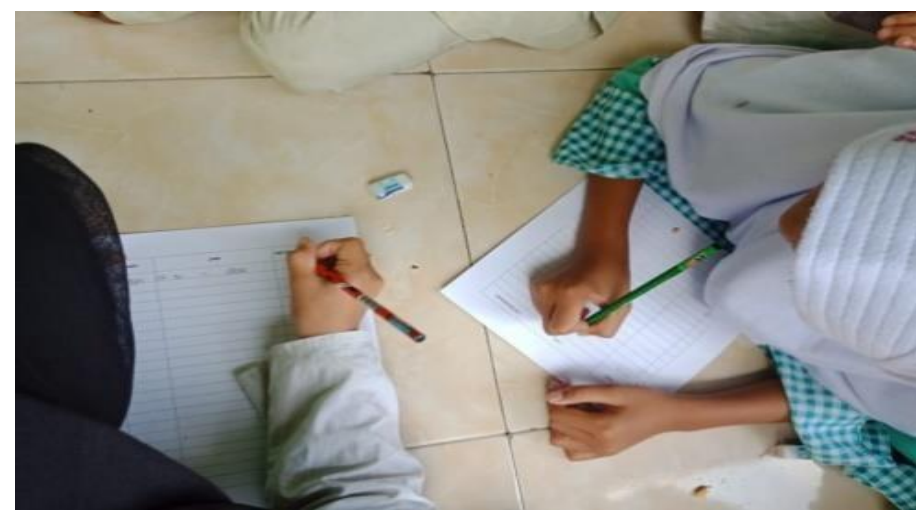

Gambar 7. Anak-anak Latihan Membuat Jadwal Harian 
5. Pembelajaran Bahasa Inggris dalam Percakapan Sehari-hari

Pada saat melakukan observasi lapangan, tim pelaksana menemukan bahwa selama komunitas MASIH memberikan pengajaran, peserta belum pernah mendapatkan pembelajaran terkait dengan Bahasa Inggris. Padahal sejatinya Bahasa Inggris sangat diperlukan, mengingat Indonesia sekarang tengah berada pada masa Revolusi Industri 4.0 di mana semua ilmu pengetahuan dan teknologi sedikit banyak menggunakan Bahasa Inggris. Maka tim pelaksana melakukan perkenalan pembelajaran Bahasa Inggris kepada peserta (anak-anak) di TPA 1 Sukawinatan tersebut melalui media bernyanyi dan bermain games susun kata, dan peserta terlihat sangat antusias mengikuti materi yang tim pelaksana ajarkan.

Dari hasil yang telah tim pelaksana dapatkan selama tim pelaksana melakukan kegiatan Program Kreativitas Mahasiswa Bidang Pengabdian kepada Masyarakat dengan judul "Kupu-kupu Tersembunyi Penerus Bangsa" dari bulan April sampai Agustus 2019 ini, tim pelaksana melihat adanya potensi berkelanjutan untuk kegiatan ini karena sifatnya yang tidak terikat pada variabel apapun dan bentuknya berupa pengabdian sehingga kegiatan ini dapat dilanjutkan kembali melalui kerjasama dengan komunitas Masyarakat Sosial Indonesia Humanity (MASIH), dan apabila berkembang secara signifikan, maka akan menjadi sebuah wadah (tempat) pembelajaran bagi mereka (anakanak) yang putus sekolah.

Melalui kegiatan Program Kreativitas Mahasiswa Bidang Pengabdian kepada Masyarakat ini pula kemampuan membaca, menulis, dan berhitung anak-anak di TPA 1 Sukawinatan semakin meningkat. Mereka mampu memahami tulisan, operasi perhitungan, dan bangun datar dengan baik sesuai dengan materi pembelajaran yang tim pelaksana berikan . Selain itu, anak-anak juga dapat lebih memahami pentingnya menabung dan pengaturan penggunaan uang secara bijak. Anak-anak juga mampu mengembangkan kreativitas mereka melalui pemanfaatan barang bekas menjadi barang lain yang memiliki nilai jual sehingga dapat membantu meringankan beban orangtua.

Di samping itu pula, anak-anak lebih memahami bagaimana cara untuk mengatur jadwal harian supaya hidup mereka lebih disiplin dan tidak melakukan hal-hal yang tidak ada manfaatnya. Selain itu anak-anak juga mempunyai modal berbahasa Inggris yang biasa digunakan secara umum dalam kehidupan seharihari. Sehingga dalam perkembangan era Revolusi Industri 4.0, anak-anak tetap bisa mengikuti dan menghadapi tantangan yang mengikuti perkembangan era tersebut.

\section{SIMPULAN DAN SARAN}

Simpulan yang dapat tim pelaksana ambil dari kegiatan Program Kreativitas Mahasiswa Bidang Pengabdian kepada Masyarakat dengan judul "Kupu-kupu Tersembunyi Penerus Bangsa" yang telah tim pelaksana lakukan dari bulan April sampai Agustus 2019 di TPA 1 Sukawinatan adalah sebagai berikut:

1. Untuk meningkatkan kemampuan membaca, menulis, dan menghitung anak-anak di TPA 1 Sukawinatan, dapat diberikan pembelajaran pola huruf dan pola bilangan bagi anak-an ak dengan jenjang usia 3 sampai 6 tahun. Sedangkan bagi anak-anak dengan jenjang usia 7 sampai 13 tahun diberikan materi perhitungan komutatif dan distributif, serta materi bangun datar. Selain itu, tim pelaksana juga memberikan apresiasi bagi peserta yang berani maju ke depan untuk menjawab setiap pertanyaan lisan yang diberikan sehingga peserta terus bersemangat dalam pembelajaran.

2. Untuk upaya penerapan sikap bijaksana dan bertanggung jawab pada peserta dalam hal penggunaan uang, dapat diberikan edukasi melalui penayangan video yang memotivasi peserta untuk mau menabung dan dijalaskan pula bagaiman cara menggunakan uang yang baik dan manfaat dari menabung itu sendiri.

3. Untuk menumbuhkembangkan keterampilan peserta dalam membuat kerajinan tangan, dapat dimulai dengan memanfaatkan barangbarang bekas (yang sudah tidak terpakai lagi) untuk dijadikan (di-recycle) sesuatu yang ememiliki nilai jual dan nilai fungsi. 
4. Untuk upaya menanamkan karakter manajemen (pengaturan) dan disiplin waktu yang baik kepada peserta dapat diberikan edukasi melalui penayangan film pendek tentang pentingnya menghargai waktu dan apa dampaknya jika kita hanya berdiam diri menunggu dan bermalas-malasan tanpa mau berproses bersama waktu. Selain itu, dapat juga memberikan mereka latihan sederhana untuk menyusun jadwal harian sebagai pedoman mereka untuk bisa menghargai waktu.

5. Untuk memperkenalkan Bahasa Inggris kepada peserta kegiatan dapat digunakan pendekatan melalui pembelajaran kosa kata Bahasa Inggris (vocabulary) dengan video lagu untuk dinyanyikan bersama dan juga dengan permainan. Selain itu dapat juga memberikan peserta latihan terkait dengan penggunaan Bahasa Inggris dalam percakapan sehari-hari.

Adapun saran dalam kegiatan ini adalah setiap anak-anak yang ada di Indonesia, baik yang bersekolah maupun yang tidak, merupakan masa depan bangsa Indonesia. Proses tercapainya tujuan dan cita-cita bangsa Indonesia ke depannya mereka yang menentukan. Oleh karena itu sedari dini mereka perlu dibimbing dalam perkembangan mental dan fisiknya, serta diberikan pembelajaran terkait dengan ilmu pengetahuan guna menambah wawasan mereka.

\section{DAFTAR PUSTAKA}

Asiah, N. (2018). Pembelajaran Calistung Pendidikan Anak Usia Dini dan Ujian Masuk Calistung Sekolah Dasar di Bandar
Lampung. Terampil: Jurnal Pendidikan dan Pembelajaran Dasar, 5(1), 19-42.

Budiono. (2017). Pemanfaatan Limbah Botol Plastik Menjadi Prakarya Boneka Pinguin Sebagai Bentuk Implementasi dari Pendidikan Lingkungan Hidup. Jurnal PINUS, 2(2), pp 113-118.

Joceylin H. (2011). Mengelola Uang Saku. Jakarta: Pakar Raya.

Lisnani, Setiawan, A.D., Stevani, A.L, \& Septian, A.I. 2020. Pendampingan Pembelajaran Matematika Operasi Perkalian Bagi Siswa SD Kelas II SDN 42 Palembang. Jurnal Terapan Abdimas, 5(1), 21-27.

NN. (2017). Soal Minat Baca Indonesia Peringkat 60 dari 61 Negara. Artikel. www.pikiranrakyat.com/pendidikan/2017/03/17/soalminat-baca-indonesiaperingkat-60-dari61-negara-396477. Diakses pada tanggal 28 September 2018

NN.

NY.

https://data.oecd.org/indonesia.htm.Diaks es pada tanggal 28 September 2018

Oktafany, dkk. (2017). Manajemen Waktu pada Mahasiswa: Studi Kualitatif pada Mahasiswa Kedokteran Universitas Lampung. Jurnal JK, 1(3), 525-529.

Undang - Undang No. 18 Tahun 2008 tentang Pengelolaan Sampah

Widya, N. (2007). Serba-Serbi Anak. Jakarta: PT Elex Media Komputindo

Yamin, M. (2017). Metode Pembelajaran Bahasa Inggris di Tingkat Dasar. Jurnal Pesona Dasar, $\quad$ 1(1), 82-97. 